DOI https://doi.org/10.30525/978-9934-26-039-1-32

\title{
РОМАНТИЧНИЙ ОБРАЗ ГЕРОЇНІ ІНТЕЛЕКТУАЛЬНОГО ТИПУ У РОМАНІ ЖОРЖ САНД «ЛЕЛІЯ»
}

\author{
Сипа Л. М. \\ кандидат філологічних наук, \\ дочент кафедри романської філології та компаративістики \\ Дрогобииького державного педагогічного університету \\ імені Івана Франка \\ м. Дрогобич, Львівська область, Украӥна \\ В ній злилися воєдино генії всіх поетів велич всіх героїв ${ }^{1}$ \\ Жорж Санд. Лелія \\ $[1$, c. 83$]$
}

Характерною особливістю романтичного світогляду став гострий розлад між ідеалом та дійсністю. Митці слова у своїх творах зображали сильних та глибокомислячих персонажів, котрі опинялися у нетипових ситуаціях та звершували незвичайні справи. Романтичні герої часто були наділені великою моральною силою, жертовністю та незалежністю думки. Окреме місце у романтичному доробку французьких романістів, зокрема у художній спадщині Віктора Гюго та Жорж Санд, посідають персонажі-мислителі, котрі розмірковують над проблемами психологічного, суспільно-політичного, релігієзнавчого, історіософського та мистецтвознавчого змісту.

Своєрідністю вирізняється образ головної героїні у романі Жорж Санд «Лелія». У передмові до твору 1839 року письменниця повторює, що «ії персонажі не цілком реальні <..> і не повністю алегоричні» $[2,350]$. Якщо кожен 3 них представляє «частину філософського інтелекту XIX століття», то головна героїня $\epsilon$ «уособленням <...> спіритуалізму того часу», який залишається «в стані потреби i піднесення, оскільки він є сутністю високого інтелекту» [2, с. 350].

У центрі твору героїня, чий інтелект здатний охопити різні питання буття. Якщо у попередніх романах Жорж Санд жінки-персонажі вирішують свої особисті проблеми, то Лелія перейнята сенсом життя, долею людства, сутністю релігії та задається питанням щодо почуття любові.

${ }^{1}$ Тут і далі переклад з французької наш. - Л. Сипа. 
У романі ідеалізується передусім фізична краса героїні, що характеризується як неперевершена. На це звертає увагу поет Стеніо та колишній галерник Тренмор. Останній бачить в Лелії поряд з фізичною вродою, «Глибоку задумливість, притаманну філософським століттям» [1, с. 82] та інтелектуальну могутність своєї епохи. Він порівнює iï 3 Галатеєю, $з$ поглядом Торквато Тассо, $з$ посмішкою Данте Аліг'єрі, а також з героями Вільяма Шекспіра. Тренмор переконаний, що «Лелія поєднує у собі цілісні ідеали» їі «світле і ясне чоло, велике та щедре серце вміщує в собі всі великі думки, всі шляхетні почуття: релігію, ентузіазм, стоїцизм, жаль, завзяття, страждання, милосердя, прощення, чистоту, сміливість, презирство до життя, розум, енергію, надію, терпіння, все!» [1, с. 83]. Лелія, на думку Тренмора, постає втіленням найкращих рис, моральних якостей та довершених переконань.

Вивищує геніальність героїні, як і інші її особливості, також Стеніо. Проте, роздумування Лелії оповиті містикою для юного поета. Йому важко зрозуміти, чи ця жінка розкриває таємниці власного життя, а чи говорить про людство в цілому. Цікаво, що Лелія вживає першу особу множини «nous» («ми»), ведучи мову і про себе, і про людей, що теж постає ознакою уособлення в образі героїні людства загалом.

«Хто ти?»- задається питанням Стеніо, звертаючись до Лелії [1, с. 7]. Саме цими словами розпочинається роман. Про Лелію відомо не багато: вона надзвичайно вродлива і розумна, у неї велика амплітуда почуттів. Стеніо здається, що серце Лелії коливається між ніжними імпульсами та непримиренною холодністю. Оригінальність та загадковість Лелії пояснюється тим, що вона передчасно прожила все, що несе собою людське життя та вичерпала його сповна. Лелії тридцять років, але видається, що вона подолала вже всі життєві труднощі й повернулася назад 3 довготривалої мандрівки. Лелія безпристрасно розмірковує на різні теми. Стеніо вражає «холодна» досконалість цієї жінки.

Сама Лелія наголошує на тому, що вона народилася на іншому краї землі і характеризує себе як дуже слабку і беззахисну людину, котра виснажена радощами та живе постійно у метушні, жадаючи якогось невідомого щастя. Зазнавши гіркоту нерозділеного кохання та розчарування, Лелія впевнена в тому, що світом керує егоїзм як непорушний і сталий закон. Життя жінки проходить без ілюзій, вона жаліє та співчуває Стеніо, поважає Тренмора.

Лелія прагне досконалості. Їі думки спрямовані на вічні пошуки недосяжного ідеалу, що і $є$ причиною протиставлення себе іншим. Лелія «мріяла про ідеал», іiі ідеал «просто розриває мрію», вона хоче «йти до ідеалу», іiі роздуми позначені «культом ідеалу». Таке тяжіння до 
довершеності відіграє руйнівну роль і стає тягарем не тільки для героїні, а й для інших: «Я забула про молодість, і природа забула розбудити мене. Мої мрії були надто піднесені. Я не могла більше зійти до апетитів матерії» [1, c. 288].

Усамітнившись на руїнах старого монастиря, Лелія піддається роздумам про страждання, яке може винести людина задля смирення. За час, проведений у повній самотності, Лелія відкрила це почуття для себе 3 новим усвідомленням: «Страждання збуджує, надихає, воно дратує, воно відкидає від серця кров, воно скорочує нам агонію. Це жорстоке, страшне потрясіння, яке відриває нас від землі і дає нам силу піднятися до неба, проклинати і кричати» [1, с. 232]. Героїня доходить висновку, що «людина, яка не страждала, нічого не варта. Це недосконала істота, марна сила, грубий і нікудишній матеріал» [1, с. 235].

Найшляхетнішим почуттям Лелія вважає любов, що може бути звернена лише до Бога. Велич любові неможливо зрозуміти людині, на думку Лелії. Почуття любові, зі слів жоржсандівської героїні, може бути скерованим лише до Бога, бо любов, - настільки велике почуття, що його неможливо отримати людині. Для Лелії Бог єдиний, хто може утримувати цю любов у своєму серці. За переконаннями героїні, люди на землі занадто слабкі, щоб прийняти любов, але продовжують накопичувати це почуття у собі, оскільки живуть у світі, де вибрали прославляти людину замість Бога. Причина, через яку ми відмовляємося від Бога, $є$ сумнівом у його існуванні. Коли Лелія не бачить Бога, вона звертається до людини, але не вірить, що ця людина може сприйняти іiі, тому замикається перед нею. Лелія потребує Бога, щоб виправдати саму себе. Вона каже: «Моє найбільше страждання - завжди боятися відсутності Бога, якого я можу ображати» [1, с. 285].

В моменти розпачу Лелія не бачить у житті нікого і нічого, окрім болісного паломництва до неясної мети. Вона вирішує чинити сама свою долю і вибирає шлях усамітнення, щоб краще пізнати себе. Проте, іiї діяльність не обмежується зосередженістю на собі. Шукаючи самотності, Лелія приходить до усвідомлення про своє громадське покликання, яке здатне бути корисним для інших. Вона йде в монастир, де у жіночій спільноті долає власне безсилля. Добровільне позбавлення волі дає героїні можливість обдумати усі перешкоди, які траплялися на її шляху до бажаного ідеалу. Ставши настоятелькою монастиря, Лелія має намір досягти рівності та братерства шляхом активної благодійності. У стінах монастиря вона проводить широку просвітницьку діяльність для жінок, вчить знедолених втішати себе та зберігати власну гідність й силу. Героїня проявляє тим самим свій дар красномовства та переконання. Під 
iii впливом інші дивляться на світ по-новому, хочуть вдосконалити як себе, так і оточуюче суспільство.

Головна героїня прагне гармонії з природою та 3 усім зовнішнім світом. Лелія, відкидаючи цивілізацію як таку, намагається гармонізувати стосунки людей, що іiї оточують. В такому ракурсі Лелія відтворена як образ людини, котра вчить розуміти життя. Вона захоплюється людьми, котрі зберегли у собі духовну молодість та здобули знання і засуджує тих, хто черпає свої сили у слабкості інших.

Певною мірою протилежністю до образу Лелії як героїні інтелектуального типу змальований у художньому світі твору поет Стеніо. Він постає як людина недосвідчена в житті. Лелія неодноразово називає його дитиною, а життєвий шлях Стеніо порівнює зі школою. Героїня впевнена, що немає потреби поспішати, щоб пізнати «школу життя». У романі Стеніо зображений як втілення незнання («ignorance»), тоді як Лелія уособлює в собі «знання».

Лелія в однойменному у романі Жорж Санд постає як виняткова романтична особистість, що втілює як моральні, так й ідейні пошуки свого часу. Героїня чітко вирізняється 3-поміж інших. Це сильна духом особистість, котра тривожно й з болем вдивляється в навколишній світ та глибоко замислюється над сутністю буття людини. Вона наділена незвичайною вродою та глибоким розумом. Вражаючою $є$ також палітра почуттів Лелії. Внутрішній спокій та здатність реалізувати себе жоржсандівська героїня знаходить в монастирі. Саме там іï фізична краса гармонійно поєднується з інтелектуальною.

\section{Література:}

1. Sand G. Lélia (édition de 1833). Bibliothèque électronique du Québec. 606 p. URL: https://beq.ebooksgratuits.com/vents/sand-lelia.pdf

2. Sand G. Préface de 1839. Lélia / George Sand. Paris, 1960. P. 348-355. 